\title{
CARTPT Gene
}

National Cancer Institute

\section{Source}

National Cancer Institute. CARTPT Gene. NCI Thesaurus. Code C147928.

This gene plays a role in the negative regulation of appetite. 